\title{
Molecular analysis reveals high diversity in the Hoplias malabaricus (Characiformes, Erythrinidae) species complex from different Amazonian localities
}

\author{
Alex M. V. Ferreira ${ }^{1 *} \odot$, Leila Braga Ribeiro², Eliana Feldberg ${ }^{1}$ \\ ${ }^{1}$ Instituto Nacional de Pesquisas da Amazônia, Programa de Pós-graduação em Genética, Conservação e Biologia Evolutiva, Manaus, Amazonas, Brazil \\ 2 Universidade Federal de Roraima, Centro de Ciências da Saúde, Av. Capitão Ene Garcêz 2413, CEP 69310-000, Boa Vista, Roraima, Brazil \\ * Corresponding author: alex.matheus.viana@gmail.com; (D) https://orcid.org/0000-0003-3969-177X
}

\begin{abstract}
DNA barcoding proposes that a fragment of DNA can be used to identify species. In fish, a fragment of cytochrome oxidase subunit I (COI) has been effective in many studies with different foci. Here we use this molecular tool to provide new insights into the cryptic diversity found in the Hoplias malabaricus species complex. Popularly known as trahira, H. malabaricus is widely distributed in South America. The clade shows molecular and cytogenetic diversity, and several studies have supported the occurrence of a complex of species. We performed molecular and karyotypic analysis of $H$. malabaricus individuals from eight Amazonian localities to assess the diversity present in the nominal taxon, and to clarify relationships within this group. We used 12 samples in cytogenetic analyses and found two karyomorphs: $2 \mathrm{n}=40(20 \mathrm{~m}+20$ sm) $($ karyomorph C) and $2 \mathrm{n}=$ $42(22 \mathrm{~m}+20 \mathrm{sm})$ (karyomorph A). We used 19 samples in molecular analyses with COI as a molecular marker, maximum likelihood analyses, and the Kimura-2-parameter evolutionary model with bootstrap support. We found karyomorph-related differentiation with bootstrap of $100 \%$. However, we found high molecular diversity within karyomorph C. The observed pattern allowed us to infer the presence of cryptic diversity, reinforcing the existence of a species complex.
\end{abstract}

KEYWORDS: trahira, DNA barcoding, karyotype, karyomorph

\section{Análise molecular revela alta diversidade no complexo de espécies Hoplias malabaricus (Characiformes, Erythrinidae) de diferentes localidades amazônicas}

\section{RESUMO}

O DNA barcoding propóe que um fragmento de DNA possa servir para identificar espécies. Em peixes, um fragmento do gene COI tem se mostrado eficaz em muitos estudos com focos diferentes. Nós usamos essa ferramenta molecular para fornecer novas informaçóes sobre a diversidade críptica encontrada no complexo de espécies Hoplias malabaricus. Popularmente conhecida como traíra, H. malabaricus tem uma ampla distribuição na América do Sul. Esse clado mostra diversidade molecular e citogenética, e vários estudos dão suporte à ocorrência de um complexo de espécies. Realizamos análises molecular e cariotípica em indivíduos de $H$. malabaricus de oito localidades amazônicas, para acessar a diversidade no taxon nominal e elucidar as relaçôes nesse grupo. Usamos 12 amostras em análises citogenéticas e encontramos dois cariomorfos: $2 \mathrm{n}=40$ (20m + 20sm) (cariomorfo C) e $2 \mathrm{n}=42(22 \mathrm{~m}+20 \mathrm{sm})$ (cariomorfo A). Usamos 19 amostras em análise molecular, utilizando COI como marcador molecular, análises de máxima verossimilhança e o modelo evolutivo de Kimura-2-parâmetros com estimativa de bootstrap. Encontramos diferenciação relacionada aos cariomorfos com bootstrap de 100\%. No entanto, encontramos alta diversidade molecular no cariomorfo C. O padráo observado nos permitiu inferir a presença de diversidade oculta, reforçando a existência de um complexo de espécies.

PALAVRAS-CHAVE: traíra, DNA barcode, cariótipo, cariomorfo

\section{INTRODUCTION}

The family Erythrinidae is composed of three genera widely distributed in South and Central-America: Hoplerythrinus (Gill 1896), Erythrinus (Scopoli 1777) and Hoplias (Gill 1903) (Nelson et al. 2016; Betancur et al. 2017). Hoplias is divided in three groups: Hoplias macrophthalmus (Pellegrin 1907), a group comprised of a single valid species; Hoplias lacerdae (Miranda Ribeiro 1908), a group currently including five valid species; and Hoplias malabaricus (Bloch 1794), a group still lacking a proper taxonomic approach (Reis et al. 2003; Oyakawa and Mattox 2009). Hoplias malabaricus is frequently 
found in temporary lakes due to its capacity to survive at low oxygen concentrations and high water temperatures (Reis et al. 2003). It also represents one of the most complex problems in Neotropical fish taxonomy (Reis et al. 2003; Mattox et al. 2014). This species shows extensive karyotypic variation, with seven karyomorphs described so far (A-G), occurring in either allopatric and sympatric conditions. The karyomorphs differ in diploid number, karyotypic formula, and some exhibit sexual chromosomes (Bertollo et al. 2000). Such diversity in this species might be related to low gene flow among populations, since $H$. malabaricus has sedentary habits (Dergam et al. 2002; Blanco et al. 2010).

In recent decades, molecular and cytogenetic analyses have formed the basis of useful new interpretations of Neotropical fish taxonomy and phylogeny (Albert and Reis 2011; Pereira et al. 2013). Among the molecular markers used for species differentiation, DNA barcoding is one of the most popular and is widely used in species classification (Ardura et al. 2010). This approach uses a DNA fragment from cytochrome oxidase subunit I (COI), which codes part of an enzyme from the electron transfer chain, as a molecular tool for either identification of species already described or to provide supportive evidence for new species (Hebert et al. 2003). This genetic tool can be used for a variety of purposes, from forensic analyses and studies for species conservation (Ardura et al. 2010; Carvalho et al. 2015; Shen et al. 2016; Barman et al. 2018) to taxonomic studies (de Borba et al. 2019). Several authors have also shown the efficiency of DNA barcoding for fish species identification (Benzaquem $e t$ al. 2015; Ferreira et al. 2017; Barendse et al. 2019).
We performed cytogenetic and molecular analyses on samples of $H$. malabaricus from eight Amazonian localities to contribute to the understanding of the relationships within this taxon, and test the efficiency of DNA barcoding for identification of this group.

\section{MATERIAL AND METHODS}

We collected 19 individuals of $H$. malabaricus in eight localities (Figure 1; Table 1). We also collected two individuals of Erythrinus erythrinus (Bloch \& Schneider, 1801) and one individual of Hoplerythrinus unitaeniatus (Spix \& Agassiz, 1829) for use as outgroup in the analyses (Table 1). Individuals were euthanized, and had their kidneys and muscle samples removed. Collection and animal handling occurred between 1995 and 2004 under SISBIO permanent license no. 280951 issued by Instituto Brasileiro do Meio Ambiente e dos Recursos Naturais Renováveis - IBAMA. Tissue samples were stored at the collection of genetic resources - INPA and the specimens were deposited in the Ichthyological Collection of Instituto Nacional de Pesquisas da Amazônia (INPA-ICT 059630, INPA-ICT 059631, INPA-ICT 059632).

\section{Cytogenetic analysis}

Kidney samples were used for chromosomal preparations, according to the protocol of Bertollo et al. (1978). We classified chromosomes as metacentric, submetacentric or acrocentric, following Levan et al. (1964). Karyomorphs were separated following Bertollo et al. (2000).

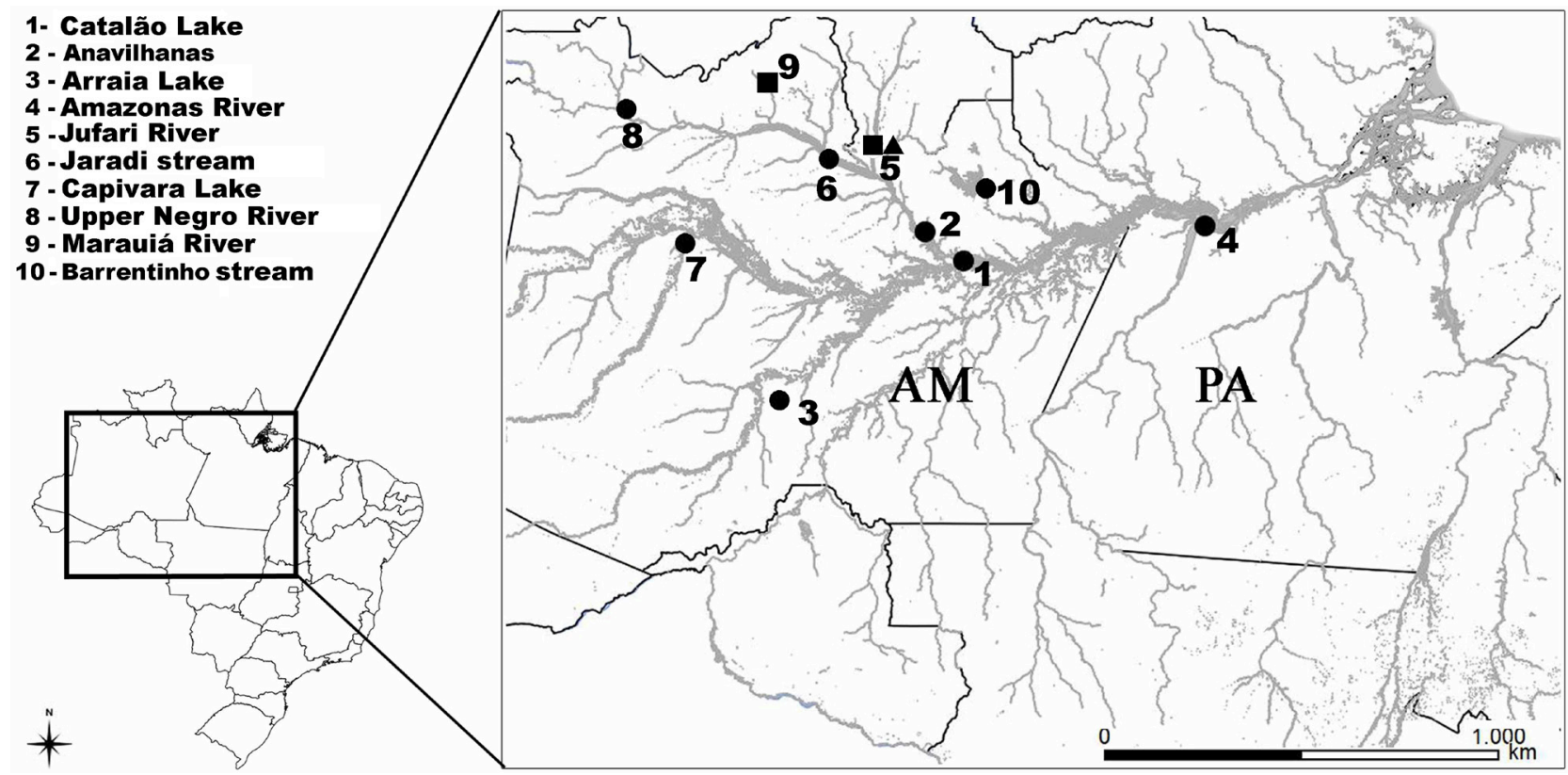

Figure 1. Map of fish collection sites in Amazonas (AM) and Pará PA) states (Brazil). • Hoplias malabaricus collection sites; Hoplerythrinus unitaeniatus collection sites; Erythrinus erythrinus collection sites. 
Table 1. Sampling sites of Hoplias malabaricus and its outgroup species (Hoplerythrinus unitaeniatus and Erythrinus erythrinus) in 10 localities in the Brazilian Amazon (see Figure 1 for site distribution). $N$ individuals $=$ number of individuals collected $\left(\sigma^{n}=\right.$ male, $q=$ female, juv $=$ juvenile).

\begin{tabular}{|c|c|c|c|c|}
\hline Sampling site & Species & $\mathrm{N}$ individuals & Geographical coordinates & Voucher numbers \\
\hline Catalão Lake & Hoplias malabaricus & $30^{x}, 29$ & $3^{\circ} 10^{\prime} 30.8^{\prime \prime S}, 9^{\circ} 56^{\prime} 30.3^{\prime \prime} \mathrm{W}$ & INPA-ICT 059630 \\
\hline Anavilhanas & Hoplias malabaricus & $20^{\pi}, 19$ & $2^{\circ} 33^{\prime} 28.4^{\prime \prime} \mathrm{S}, 60^{\circ} 46^{\prime} 29.7^{\prime \prime} \mathrm{W}$ & INPA-ICT 059630 \\
\hline Arraia Lake & Hoplias malabaricus & 1 juv & $3^{\circ} 96^{\prime} 03.09^{\prime \prime} \mathrm{S}, 62^{\circ} 80^{\prime} 44.97^{\prime \prime} \mathrm{W}$ & INPA-ICT 059630 \\
\hline Amazonas River & Hoplias malabaricus & 2 juv & $2^{03} 8^{\prime} 10.36^{\prime \prime} \mathrm{S}, 54^{\circ} .72^{\prime} 79.14^{\prime \prime} \mathrm{W}$ & INPA-ICT 059632 \\
\hline Jufari River & Erythrinus erythrinus & $10^{7}$ & $0^{\circ} 99^{\prime} 95.59^{\prime \prime} \mathrm{S}, 62^{\circ} 19^{\prime} 28.22^{\prime \prime} \mathrm{W}$ & INPA-ICT 059632 \\
\hline Jaradi Stream & Hoplias malabaricus & $20^{n}, 19$ & $0^{\circ} 99^{\prime} 82.01^{\prime \prime S}, 62^{\circ} 88^{\prime} 05.44^{\prime \prime} \mathrm{W}$ & INPA-ICT 059631 \\
\hline Capivara Lake & Hoplias malabaricus & $10^{\pi}, 19$ & $3036^{\prime} 65.84^{\prime \prime} \mathrm{S}, 64075^{\prime} 30.20^{\prime \prime} \mathrm{W}$ & INPA-ICT 059631 \\
\hline Negro River & Hoplias malabaricus & 1 juv & $0^{\circ} 12^{\prime} 36.58^{\prime \prime S}, 67^{\circ} 09^{\prime} 87.75^{\prime \prime} \mathrm{W}$ & INPA-ICT 059631 \\
\hline Marauaia River & $\begin{array}{l}\text { Erythrinus erythrinus } \\
\text { Hoplerythrinus unitaeniatus }\end{array}$ & $\begin{array}{l}10^{x} \\
10^{x}\end{array}$ & $0^{\circ} 35^{\prime} 31.26^{\prime \prime} \mathrm{S}, 65^{\circ} 07^{\prime} 87.09^{\prime \prime} \mathrm{W}$ & INPA-ICT 059632 \\
\hline Barrentinho Stream & Hoplias malabaricus & 29 & $1^{\circ} 10^{\prime} 46.82^{\prime \prime} \mathrm{S}, 60^{\circ} 43^{\prime} 09.81^{\prime \prime} \mathrm{W}$ & INPA-ICT 059631 \\
\hline
\end{tabular}

\section{DNA extraction and PCR}

For molecular analyses, we used 19 individuals of $H$. malabaricus, and two E. erythrinus and one H. unitaeniatus as outgroup. Total DNA was extracted using the Wizard Extraction Kit (Promega) according to the manufacturer's recommendations, and quantified on a NanoVue Plus spectrophotometer (GE Healthcare). COI amplification was performed in a thermal cycler (T100 ${ }^{\mathrm{TM}}$ Thermal Cycler), using the following primers: VR1 5' CAG GAA ACA GCT ATG ACT AGA CTT CTG GGT GGC CAA AGA ATC A 3' and VF1 5' TGT AAA ACG CGG CCA GTT CT CAA CCA CAA AGA CAT TGG 3' (Ivanova et al. 2007). Amplification was conducted using 35 cycles with the following profile: 92 ${ }^{\circ} \mathrm{C}$ for $30 \mathrm{sec}, 56^{\circ} \mathrm{C}$ for $30 \mathrm{sec}$ and $72^{\circ} \mathrm{C}$ for $1 \mathrm{~min} 30 \mathrm{sec}$.

\section{DNA sequencing}

Polymerase Chain Reaction (PCR) products were visualized on a $1.7 \%$ agarose gel, and purified with $20 \%$ polyethylene glycol (PEG) (Lis 1980). For sequencing, a Big Dye Sequence Terminator v.3.1 kit (Applied Biosystems) was used, according to manufacturer instructions. Amplification conditions comprised 25 cycles at $96^{\circ} \mathrm{C}$ for $30 \mathrm{sec} ; 15 \mathrm{sec}$ at $50^{\circ} \mathrm{C}$; and 4 $\min$ at $60^{\circ} \mathrm{C}$. Subsequently, reaction products were precipitated and sequenced (sequencer model ABI PRISM 3100 Genetic Analyzer from Applied Biosystems/made by HITACHI).

\section{Barcoding analysis}

We used 22 COI sequences with 600 bp to perform the molecular analyses, which were aligned using the GeneiousR 10.1.3 software. Kimura-2 distance model parameters (Kimura 1980) were used to build a Maximum Likelihood (ML) tree, created to provide a graphic representation of the relationships between individuals and clusters using GeneiousR 10.1.3 software, and a bootstrap analysis was performed (Felsenstein 1985) with 1,000 replicates. We used the other two Erythrinidae genera (Erythrinus and Hoplerythrinus) as an outgroup. All sequences obtained in this study are available on GenBank (https://www.ncbi.nlm.nih. gov/genbank/), accession numbers MT076970-MT076984. In addition, we used sequences from the BOLD Systems (https://www.boldsystems.org/) to build a ML tree to produce a more robust imterpretation of our results (accession numbers BFFDF148-19; BSB280-10 -BSB492-10; CYTC4372-12; DSFRE175-08 - DSFRE178-08; FUPR169-09 - FUPR17109; GBMNB11689-20 - GBMNB12169-20; HPRB006-16 HPRB024-16; ITAPE092-15 - ITAPE131-15; JEQUI041-12 - JEQUI210-13; LARI001-12 - LARI128-12; MUCU03013 - MUCU086-13; RDOCE022-13 - RDOCE099-13; RENA032-16 - RENA039-16; UDEA133-18).

\section{RESULTS}

The COI fragment contained $600 \mathrm{bp}$, and the Blast analysis indicated that most samples were correctly identified as $H$. malacaricus. All individuals belonging to $H$. malabaricus formed a group with $100 \%$ bootstrap support, but we also found four different linages, which were classified as Evolutionary Significant Units (ESUs). ESU-A: samples from Barcelos (Jaradi Stream) + Arraia Lake (corresponding to karyomorph A); ESU-B: samples from Barrentinho Stream + Negro River + Capivara Lake and Catalão Lake; ESU-C: Capivara lake + Cataláo Lake and Anavilhanas; and ESU-D: samples from the Amazonas River. Noticeably, we found two different ESUs (B and $\mathrm{C}$ ) occurring in the same localities (Capivara Lake and Catalăo Lake). In addition, the other species of Erythrinidae demonstrated robust bootstrap values. Our two E. erythrinus outgroup samples formed a clade with $100 \%$ bootstrap support, and the analysis supported a clade formed by E. erythrinus $+H$. unitaeniatus with 100\% support (Figure 2).

The complementary analysis with BOLD sequences showed that our samples from Jaradi Stream and Arraia Lake (ESU A) shared a cluster with samples from Negro River, Barrentinho Stream (ESU B), and sequences from Caracas (Venezuela). Samples from ESU C shared a cluster with sequences 


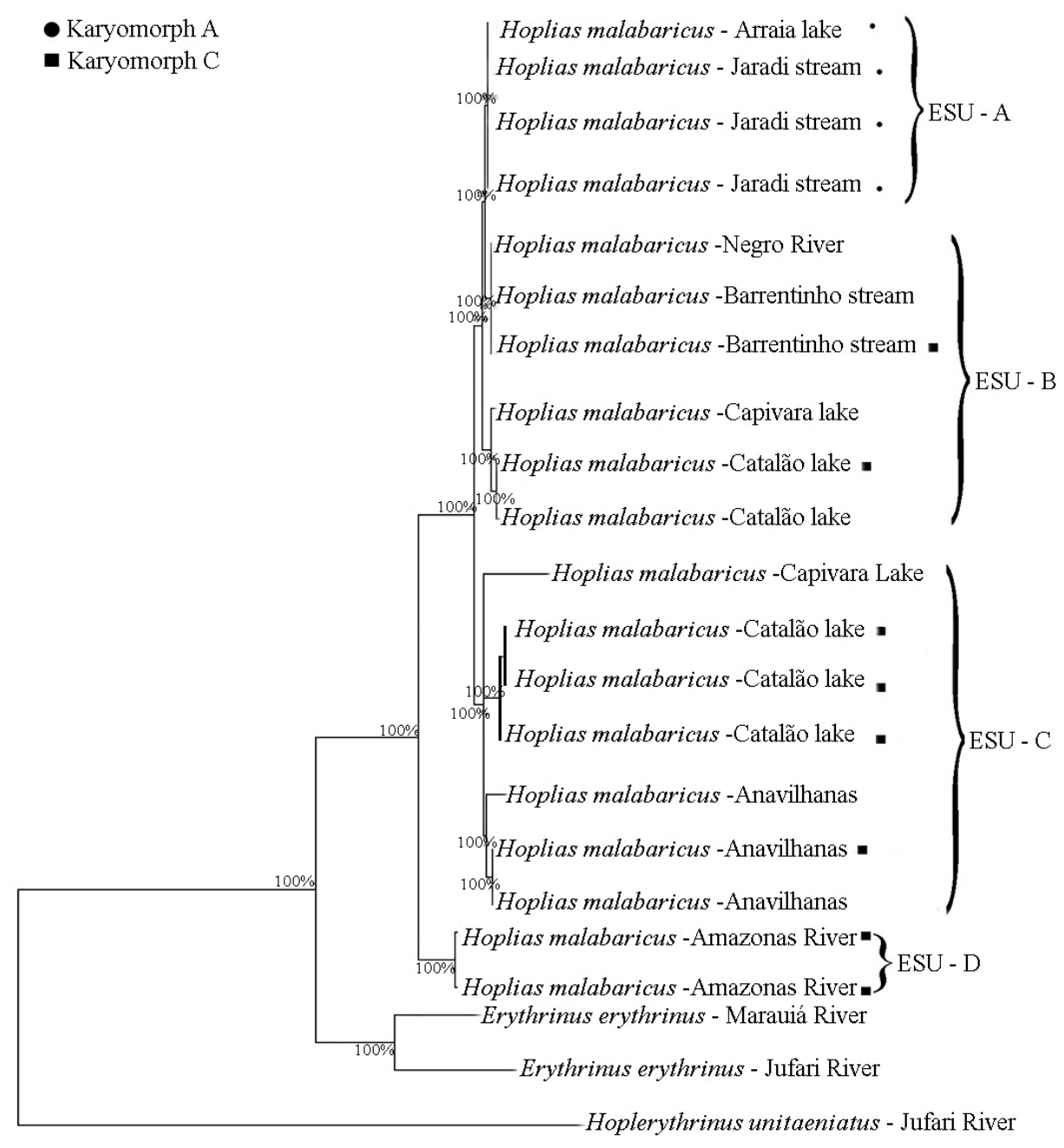

Figure 2. Phylogenetic relationships of COI haplotypes derived from Hoplias malabaricus karyomorphs and its outgroups. The topology was obtained with maximum likelihood analysis. Bootstrap values equal 100\% for all clusters.

from Minas Gerais (Brazil), and Buenos Aires (Argentina). Additionally, this cluster was close to sequences from Maranhão (Brazil). ESU D shared a cluster with sequences from Paraná (Brazil) (Supplementary Material, Figure S1).

We only obtained cytogenetic results for 12 of the 19 collected individuals of $H$. malabaricus. Cytogenetically analyzed individuals showed two karyotypes, karyomorph A $(2 \mathrm{n}=42,22 \mathrm{~m}+20 \mathrm{sm})$ and karyomorph C $(2 \mathrm{n}=40,20 \mathrm{~m}+$ 20sm) (Figure 3), both of which have already been described for the species. Karyomorph A was found in samples from Jaradi stream and Arraia Lake (ESU A), while karyomorph C was found in samples from Cataláo Lake, Barrentinho Stream, Anavilhanas, and Amazon River (ESU B, C and D). We did not record any sex-related differentiation at the karyotypic level.
A

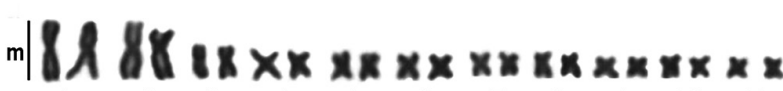
$\begin{array}{lllllllllll}1 & 2 & 3 & 4 & 5 & 6 & 7 & 8 & 9 & 10 & 11\end{array}$

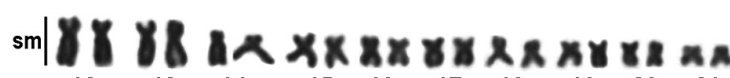
B $\begin{array}{llllllllll}12 & 13 & 14 & 15 & 16 & 17 & 18 & 19 & 20 & 21\end{array}$

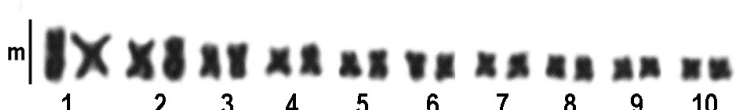

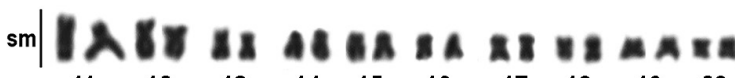
$\begin{array}{llllllllll}11 & 12 & 13 & 14 & 15 & 16 & 17 & 18 & 19 & 20\end{array}$ 10.0 um

Figure 3. Karyotypes of Hoplias malabaricus using Giemsa stain showing karyomorph A (A), and karyomorph C (B). 


\section{DISCUSSION}

Despite having its efficiency questioned (Blaxter 2004), DNA barcoding has demonstrated its efficiency in resolving a variety of problems related to identification of species and species complexes (Hubert et al. 2016; Ferreira et al. 2017). We confirmed the efficiency of this molecular tool, which revealed identification mistakes made by the use of morphological characteristics alone, showing the potential of DNA barcoding to confirm field identifications, detect misidentifications and uncover cryptic diversity. Furthermore, we observed a division between populations and karyomorphs $(2 \mathrm{n}=40$ and $2 \mathrm{n}=$ 42), suggesting that karyotypic variation in $H$. malabaricus is a consequence of different chromosomal rearrangements occurring independently in different areas of the distribution range of the species. Guimarães et al. (2017) compared two populations of karyomorph $\mathrm{A}$, and found differences related to centromere position, number and location of nucleolar organizer regions (NORs), and organization patterns of heterochromatic regions, demonstrating that evolutionary divergence has occurred within these groups to some degree. This karyotypic pattern is supported by the sedentary habit of $H$. malabaricus, which may result in restricted gene flow (Dergam et al. 2002; Blanco et al. 2010).

Our results show low molecular differentiation between ESU A, ESU B and ESU C, which indicates that $H$. malabaricus karyomorphs $\mathrm{A}$ and $\mathrm{C}$ may hybridize, although no intermediate karyomorph has ever been found (e.g. $2 \mathrm{n}=41$ ), even in the areas where both $\mathrm{A}$ and $\mathrm{C}$ are found in sympatry (Bertollo et al. 2000). However, we did not find karyomorph $F$, which is similar to karyomorph C, except for the presence of a metacentric pair, the first in the karyotype (Bertollo et al. 2000). Furthermore, variations can be found in the same karyomorph, as reported for karyomorph A from the upper Paraná River basin (Blanco $e t$ al. 2010), and karyomorphs $A$ and $C$ from the Central Amazon (Guimarães et al. 2017). Taken together, all previous evidence indicates that this species group is characterized by very high levels of cytogenetic and molecular variation.

Such diversity has also been shown at the molecular level. Recently, using the COI gene, Cardoso et al. (2018) revealed the existence of high levels of diversity within members of the genus Hoplias collected in South America, with 15 fully supported mitochondrial linages within what was once considered to be a single species, $H$. malabaricus, with a continental-wide distribution. Only four of these lineages are currently described as valid species, leaving 11 mitochondrial lineages still hidden within the species complex. The same study highlighted the existence of different linages within the $H$. lacerdae group, hinting at the complexity within Hoplias. Also based on COI analyses, Marques et al. (2013) found six haplogroups for populations of $H$. malabaricus from seven locations in Pará state (Brazil), yet all individuals had the karyomorph C $(2 \mathrm{n}=$ 40). In a study with $H$. malabaricus from populations in eastern
Brazil, Santos et al. (2009) found genetic differentiation using ATPase6 as molecular marker, two karyomorphs [A $(2 \mathrm{n}=42)$ and $\mathrm{F}(2 \mathrm{n}=40)]$, and six haplogroups.

Barcode DNA has been used to reveal cryptic diversity in other fish groups. For example, Benzaquem et al. (2015) found high levels of divergence in the genus Nannostomus, which suggests the presence of cryptic species. Likewise, barcoding and cytogenetic data indicated great divergence among Ancitrus species from the Amazonas and Paraguay basins, and the molecular tool efficiently discriminated Ancistrus lineages, indicating the occurrence of cryptic species in these regions (de Borba et al. 2019). In the current study, we found great differentiation between samples from the Amazonas River and the other sampled localities, as well as the segregation between karyomorphs A and C, suggesting that different processes are acting on the populations of Amazonian trahira, which can lead to full speciation. In view of this variation within karyomorphs, the karyotype classification previously proposed by Betorllo et al. (2000) is insufficient for describing phylogenetic relationships within this species complex.

\section{CONCLUSIONS}

The pattern in our cytogenetics and molecular data indicates the presence of distinct lineages of Hoplias malabaricus in the Amazonas basin and support the existence of a species complex. The use of nuclear markers would be needed to clarify the processes related to $H$. malabaricus population structure and dynamics. In addition, comparative analyses with of other regions would also be necessary to understand the evolutionary history and biogeographic patterns of this group.-

\section{ACKNOWLEDGMENTS}

The authors are grateful to the Brazilian institutions, Instituto Nacional de Pesquisas da Amazônia (INPA), Fundação de Amparo à Pesquisa do Estado do Amazonas (FAPEAM), Coordenação de Aperfeiçoamento de Pessoal de Nível Superior (CAPES) and Conselho Nacional de Desenvolvimento Científico e Tecnológico (CNPq). AMVF was a student of Programa de Apoio à Iniciação Científica do Amazonas (PAIC) and received a fellowship from FAPEAM. The authors also thank Dr. Jorge Ivan Rebelo Porto for collecting the fish and discussing the data and special thanks to Arlindo Batista for all the support provided in the laboratory.

\section{REFERENCES}

Albert, J.S.; Reis, R. 2011. Historical Biogeography of Neotropical Freshwater Fishes. University of California Press, Berkeley, p.119-136.

Ardura, A.; Linde, A.R.; Moreira, J.C.; Garcia-Vazquez, E. 2010. DNA barcoding for conservation and management of Amazonian commercial fish. Biological Conservation, 143: 1438-1443. 
Barendse, J.; Roel, A.; Longo, C.; Andriessen, L.; Webster, L.M.I.; Ogden, R.; et al. 2019. DNA barcoding validates species labelling of certified seafood. Current Biology, 29: R198-R199.

Barman, A.S.; Singh, M.; Singh, S.K.; Saha, H.; Singh, Y.J.; Laishram, M.; et al. 2018. DNA barcoding of freshwater fishes of indo-myanmar biodiversity hotspot. Scientific Reports, 8: 8579. doi.org/10.1038/s41598-018-26976-3

Benzaquem, D.C.; Oliveira, C.; Da Silva Batista, J.; Zuanon, J.; Porto, J.I.R. 2015. DNA barcoding in pencilfishes (Lebiasinidae: Nannostomus) reveals cryptic diversity across the Brazilian Amazon. PLoS ONE, 10: e0123363.

Bertollo, L.A.C. 1978. Cytotaxonomic considerations on Hoplias lacerdae (Pisces, Erythrinidae). Brazilian Journal Genetics, 1: 103-120.

Bertollo, L.A.C.; Born, G.G.; Dergam, J.A.; Fenocchio, A.S.; Moreira-Filho, O. 2000. A biodiversity approach in the neotropical Erythrinidae fish, Hoplias malabaricus. Karyotypic survey, geographic distribution of cytotypes and cytotaxonomic considerations. Chromosome Research, 8: 603-613.

Betancur, R.R.; Wiley, E.O.; Arratia, G.; Acero, A.; Bailly, N.; Miya, M.; et al. 2017. Phylogenetic classification of bony fishes. BMC Evolutionary Biology, 17: 162. doi.org/10.1186/s12862-017-0958-3

Blanco, D.R.; Lui, R.L.; Bertollo, L.A.C.; Diniz, D.; Filho, O.M. 2010. Characterization of invasive fish species in a river transposition region: Evolutionary chromosome studies in the genus Hoplias (Characiformes, Erythrinidae). Reviews in Fish Biology and Fisheries, 20: 1-8. doi.org/10.1007/s11160-009-9116-3

Blaxter, M.L. 2004. The promise of a DNA taxonomy. Philosophical Transactions of the Royal Society of London. Series B: Biological Sciences, 359: 669-679.

de Borba, R.S.; Mariotto, S.; Centofante, L.; Henrique Zawadzki, C.; Pasquali Parise-Maltempi, P. 2019. Molecular discrimination of Ancistrus lineages (Siluriformes: Loricariidae) using barcode DNA tool. Mitochondrial DNA Part A: DNA Mapping, Sequencing, and Analysis, 30: 602-608.

Cardoso, Y.P.; Rosso, J.J.; Mabragańa, E.; González-Castro, M.; Delpiani, M.; Avigliano, E.; et al. 2018. A continental-wide molecular approach unraveling mtDNA diversity and geographic distribution of the Neotropical genus Hoplias. PLoS ONE, 13: e0202024.

Carvalho, D.C.; Palhares, R.M.; Drummond, M.G.; Frigo, T.B. 2015. DNA Barcoding identification of commercialized seafood in South Brazil: A governmental regulatory forensic program. Food Control, 50: 784-788.

Dergam, J.A.; Paiva, S.R.; Schaeffer, C.E.; Godinho, A.L.; Vieira, F. 2002. Phylogeography and RAPD-PCR variation in Hoplias malabaricus (Bloch, 1794) (Pisces, Teleostei) in southeastern Brazil. Genetics and Molecular Biology, 25: 379-387.

Felsenstein, J. 1985. Confidence limits on phylogenies: an approach using the bootstrap. Evolution, 39: 783-791.

Ferreira, M.; Garcia, C.; Matoso, D.A.; de Jesus, I.S.; Cioff, M. de B.; Bertollo, L.A.C.; et al. 2017. The Bunocephalus coracoideus species complex (Siluriformes, Aspredinidae). Signs of a speciation process through chromosomal, genetic and ecological diversity. Frontiers in Genetics 8: 120. doi: 10.3389/fgene.2017.00120

Guimarães, E.M.C.; Carvalho, N.D.M.; Schneider, C.H.; Feldberg, E.; Gross, M.C. 2017. Karyotypic Comparison of Hoplias malabaricus (Bloch, 1794) (Characiformes, Erythrinidae) in Central Amazon. Zebrafish, 14: 80-89.

Hebert, P.D.N.; Cywinska, A.; Ball, S.L.; Dewaard, J.R. 2003. Biological identifications through DNA barcodes. Proceedings of the Royal Society of London. Series B: Biological Sciences, 270: 313-321.

Hubert, N.; Kadarusman; Wibowo, A.; Busson, F.; Caruso, D.; Sulandari, S.; et al. 2016. DNA Barcoding Indonesian freshwater fishes: challenges and prospects. DNA Barcodes, 3: 144-169.

Ivanova, N. V; Zemlak, T.S.; Hanner, R.H.; Hebert, P.D.N. 2007. Universal primer cocktails for fish DNA barcoding. Molecular Ecology Notes, 7: 544-548.

Kimura, M. 1980. A simple method for estimating evolutionary rates of base substitutions through comparative studies of nucleotide sequences. Journal of molecular evolution, 16: 111-120.

Levan, A.; Fredga, K.; Sandberg, A.A. 1964. Nomenclature for centromeric position on chromosomes. Hereditas, 52: 201-220.

Lis, J.T. 1980. Fractionation of DNA fragments by polyethylene glycol induced precipitation. Methods in Enzymology, 65: 347-353.

Marques, D.F.; Santos, F.A. dos; Silva, S.S. da; Sampaio, I.; Rodrigues, L.R.R. 2013. Cytogenetic and DNA barcoding reveals high divergence within the trahira, Hoplias malabaricus (Characiformes: Erythrinidae) from the lower Amazon River. Neotropical Ichthyology, 11: 459-466.

Mattox, G.M.T.; Bifi, A.G.; Oyakawa, O.T. 2014. Taxonomic study of Hoplias microlepis (Günther, 1864), a trans-Andean species of trahiras (Ostariophysi: Characiformes: Erythrinidae). Neotropical Ichthyology, 12: 343-352.

Nelson, J.S.; Grande, T.C.; Wilson, M.V.H. 2016. Fishes of the World. 5th ed. John Wiley \& Sons, 752p.

Oyakawa, O.T.; Mattox, G.M.T. 2009. Revision of the Neotropical trahiras of the Hoplias lacerdae species-group (Ostariophysi: Characiformes: Erythrinidae) with descriptions of two new species. Neotropical Ichthyology, 7: 117-140.

Pereira, T.L.; Santos, U.; Schaefer, C.E.; Souza, G.O.; Paiva, S.R.; Malabarba, L.R.; et al. 2013. Dispersal and vicariance of Hoplias malabaricus (Bloch, 1794) (Teleostei, Erythrinidae) populations of the Brazilian continental margin. Journal of Biogeography, 40: 905-914.

Reis, R.E.; Kullander, S.O.; Ferraris, C.J. 2003. Checklist of the Freshwater Fishes of South and Central America. EDIPUCRS. Porto Alegre, $729 \mathrm{p}$

Santos, U.; Völcker, C.M.; Belei, F.A.; Cioffi, M.B.; Bertollo, L.A.C.; Paiva, S.R.; et al. 2009. Molecular and karyotypic phylogeography in the Neotropical Hoplias malabaricus (Erythrinidae) fish in eastern Brazil. Journal of Fish Biology, 75: 2326-2343.

Shen, Y.; Guan, L.; Wang, D.; Gan, X. 2016. DNA barcoding and evaluation of genetic diversity in Cyprinidae fish in the midstream of the Yangtze River. Ecology and Evolution, 6: 2702-2713.

RECEIVED: $30 / 05 / 2020$

ACCEPTED: $11 / 02 / 2021$

ASSOCIATE EDITOR: Izeni P. Farias

This is an Open Access article distributed under the terms of the Creative Commons Attribution License, which permits unrestricted use, distribution, and reproduction in any medium, provided the original work is properly cited. 
SUPPLEMENTARY MATERIAL (only available in the electronic version)

Ferreira et al. Molecular analysis reveals high diversity in the Hoplias malabaricus (Characiformes, Erythrinidae) species complex from different Amazonian localities

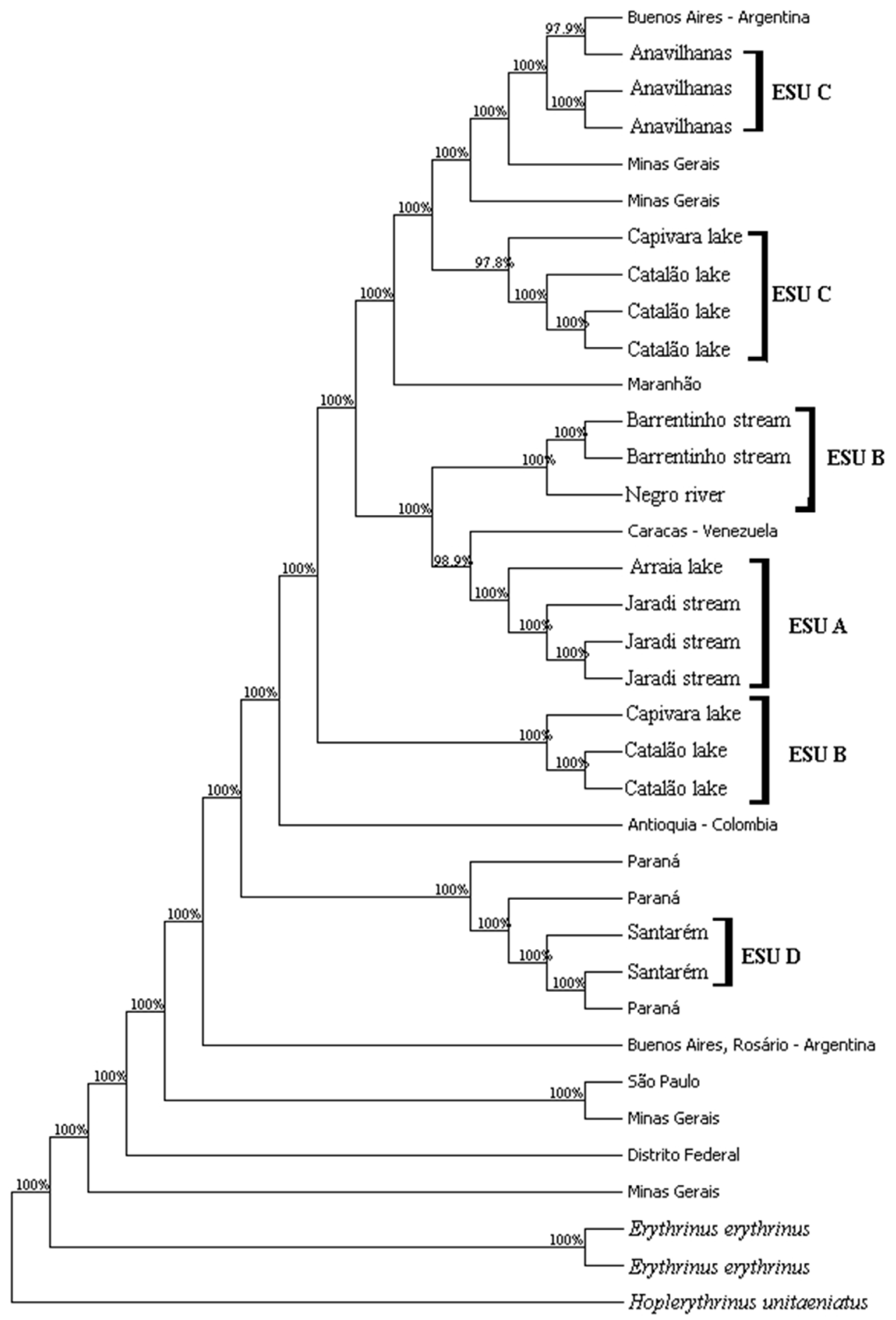

Figure S1. Phylogenetic relationships of COI haplotypes derived from Hoplias malabaricus karyomorphs from the Amazon region, its outgroups and BOLD sequences. The topology was obtained with maximum likelihood analysis. Bootstrap values are indicated at the nodes. 